\title{
A pilot study examining the relationship among Crohn disease activity, glucagon-like peptide-2 signalling and intestinal function in pediatric patients
}

\author{
David L Sigalet MD PhD¹, Dragan Kravarusic MD², Decker Butzner MD¹, Bolette Hartmann MSc PhD³, \\ Jens J Holst MD PhD ${ }^{3}$, Jon Meddings BMSc MD
}

\begin{abstract}
DL Sigalet, D Kravarusic, D Butzner, B Hartmann, JJ Holst, J Meddings. A pilot study examining the relationship among Crohn disease activity, glucagon-like peptide-2 signalling and intestinal function in pediatric patients. Can J Gastroenterol $2013 ; 27(10): 587-592$.
\end{abstract}

BACKGROUND/OBJECTIVES: The relationship between the enteroendocrine hormone glucagon-like peptide 2 (GLP-2) and intestinal inflammation is unclear. GLP- 2 promotes mucosal growth, decreases permeability and reduces inflammation in the intestine; physiological stimulation of GLP-2 release is triggered by nutrient contact. The authors hypothesized that ileal Crohn disease (CD) affects GLP-2 release.

METHODS: With ethics board approval, pediatric patients hospitalized with CD were studied; controls were recruited from local schools. Inclusion criteria were endoscopy-confirmed CD (primarily of the small intestine) with a disease activity index $>150$. Fasting and postprandial GLP-2 levels and quantitative urinary recovery of orally administered 3-O-methyl-glucose (active transport) and lactulose/mannitol (passive) were quantified during the acute and remission phases.

RESULTS: Seven patients (mean [ \pm SD] age $15.3 \pm 1.3$ years) and 10 controls $(10.3 \pm 1.6$ years $)$ were studied. In patients with active disease, fasting levels of GLP-2 remained stable but postprandial levels were reduced. Patients with active disease exhibited reduced glucose absorption and increased lactulose/mannitol recovery; all normalized with disease remission. The change in the lactulose/mannitol ratio was due to both reduced lactulose and increased mannitol absorption. CONCLUSIONS: These findings suggest that pediatric patients with acute ileal CD have decreased postprandial GLP-2 release, reduced glucose absorption and increased intestinal permeability. Healing of CD resulted in normalization of postprandial GLP-2 release and mucosal functioning (nutrient absorption and permeability), the latter due to an increase in mucosal surface area. These findings have implications for the use of GLP-2 and feeding strategies as a therapy in CD patients; further studies of the effects of inflammation and the GLP-2 axis are recommended.

Key Words: 3-O-methyl glucose; Intestinal permeability; Lactulose; Mannitol; Nutrient absorption

The enteroendocrine trophic hormone glucagon-like peptide-2 1 (GLP-2) has been shown to promote mucosal growth in the small intestine, which, over time, increases fluid, electrolyte and nutrient transport (1-4). GLP-2 is a component of the physiological regulation of intestinal nutrient transport capacity. Under normal conditions, GLP-2 release is triggered by direct nutrient contact with L-cells, which are primarily located in the distal ileum and colon. L-cells extend from the cell body resting on the basal side of the mucosal basement membrane to the mucosal surface so that the cell can 'taste' the content of the intestinal chyle $(5,6)$. This phenomenon is further
Une étude pilote sur le lien entre l'activité de la maladie de Crohn, la signalisation du peptide 2 de type glucagon et la fonction intestinale chez les patients d'âge pédiatrique

HISTORIQUE ET OBJECTIFS : On comprend mal le lien entre le
peptide 2 de type glucagon (GLP-2), une hormone entéroendocrinienne,
et l'inflammation intestinale. Le GLP-2 favorise la croissance des muqueuses
et réduit la perméabilité et l'inflammation de l'intestin. La stimulation
physiologique pour libérer le GLP-2 est déclenchée par contact avec des
nutriments. Les auteurs ont postulé que la maladie de Crohn (MC) iléale
influe sur la libération de GLP-2. MÉTHODOLOGIE : Avec l'approbation du comité d'éthique, des patients d'âge pédiatrique hospitalisés en raison d'une $\mathrm{MC}$ ont fait l'objet d'une étude. Les chercheurs ont recruté des sujets témoins dans les écoles locales. Les critères d'inclusion étaient une MC confirmée par endoscopie (principalement de l'intestin grêle) dont l'indice d'activité était supérieur à 150. Les chercheurs ont quantifié le taux de GLP-2 à jeun et après le repas et la récupération quantitative dans les urines du 3-O-méthyl-glucose (transport actif) et du lactulose/mannitol (passif) pendant la phase aiguë et la rémission.

RÉSULTATS : Les chercheurs ont étudié sept patients (d'un âge moyen [ $\pm E ́ T]$ de $15,3 \pm 1,3$ ans) et dix sujets témoins (10,3 $\pm 1,6$ ans). Chez les patients présentant une maladie en phase active, le taux de GLP-2 à jeun est demeuré stable, mais il était moins élevé après le repas. Ces patients présentaient une absorption réduite du glucose et une récupération accrue du lactulose/mannitol, les taux se normalisant en période de rémission. Le changement de ratio entre le lactulose et le mannitol était attribuable à la fois à l'absorption réduite du lactulose et à l'absorption accrue du mannitol.

CONCLUSIONS : D'après ces observations, les patients d'âge pédiatrique ayant une $\mathrm{MC}$ iléale aiguë présentent une libération moins élevée de GLP-2 après le repas, une absorption de glucose réduite et une perméabilité intestinale accrue. La rémission de la MC s'associait à une normalisation de la libération de GLP-2 après le repas et de la fonction muqueuse (absorption des nutriments et perméabilité), laquelle était attribuable à une augmentation de la surface muqueuse. Ces observations ont des conséquences sur l'utilisation du GLP-2 et des stratégies d'alimentation pour traiter les patients atteints d'une MC. Des études plus approfondies sur les effets de l'inflammation et de l'axe du GLP-2 sont recommandées.

modified by neuronal input (5). In the paradigm of patients with short bowel syndrome, the increased delivery of intraluminal nutrients (especially fats) to L-cells results in an increased postprandial GLP-2 response compared with controls $(7,8)$; it is the postprandial levels that appear to be relevant because basal levels remain stable. In turn, GLP-2 acts to slow proximal motility and, in doing so, likely acutely improves nutrient contact with the absorptive mucosa and, over time, increases mucosal mass and nutrient absorptive capacity $(8,9)$.

The interplay between GLP-2 in the physiological regulation of nutrient absorption and the pathophysiological state of intestinal

${ }^{1}$ Gastrointestinal Research Group, Snyder Institute of Infection, Immunity and Inflammation, Deparment of Surgery, Faculty of Medicine, University of

Calgary, Calgary, Alberta; ${ }^{2}$ Deptartment of Surgery, University of Tel Aviv, Tel Aviv, Israel; 3 Panum Institute, University of Copenhagen,

Copenhagen, Denmark

Correspondence: Dr David L Sigalet, University of Calgary/Alberta Children's Hospital Department of Surgery, 2888 Shaganappi Trail Northwest, Calgary,

Alberta T3B 6A8. Telephone 403-955-2271, fax 403-955-7634, e-mail sigalet@ucalgary.ca

Received for publication October 22, 2012. Accepted June 2, 2013 
TABLE 1

\section{Patient characteristics}

\begin{tabular}{|c|c|c|c|c|c|c|c|}
\hline \multirow[b]{2}{*}{ Patien } & \multirow[b]{2}{*}{$\begin{array}{l}\text { Age, } \\
\text { years }\end{array}$} & \multirow[b]{2}{*}{ Sex } & \multirow[b]{2}{*}{$\begin{array}{l}\text { Tanner } \\
\text { stage }\end{array}$} & \multicolumn{2}{|c|}{ Disease classification } & \multicolumn{2}{|c|}{$\begin{array}{c}\text { Prestudy } \\
\text { characteristics }\end{array}$} \\
\hline & & & & Localization & $\begin{array}{l}\text { Method } \\
\text { of Dx }\end{array}$ & $\begin{array}{c}\text { Duration } \\
\text { of } S x\end{array}$ & $\begin{array}{c}\text { Prestudy } \\
\text { therapy }\end{array}$ \\
\hline 1 & 13 & M & 3 & Ileum & Endo + Bx & $6 \mathrm{~m}$ & Steroids \\
\hline 2 & 15 & $\mathrm{~F}$ & 3 & Ileum & Endo + Bx & $3 \mathrm{~m}$ & None \\
\hline 3 & 15 & M & 4 & Ileum+colon & Endo + Bx & $10 \mathrm{~m}$ & Flagyl* \\
\hline 4 & 11 & M & 2 & $\begin{array}{l}\text { Ileum + } \\
\text { colon }\end{array}$ & Endo + Bx & $6 \mathrm{~m}$ & 5-ASA \\
\hline 5 & 17 & $\mathrm{~F}$ & 3 & Ileum & Endo + Bx & $18 \mathrm{~m}$ & $\begin{array}{l}\text { 5-ASA, } \\
\text { Steroids }\end{array}$ \\
\hline 6 & 14 & $\mathrm{~F}$ & 3 & $\begin{array}{l}\text { lleum + } \\
\text { colon }\end{array}$ & Endo + Bx & $1 \mathrm{~m}$ & None \\
\hline 7 & 18 & $\mathrm{~F}$ & 4 & $\begin{array}{l}\text { Ileum + } \\
\text { colon }\end{array}$ & Endo + Bx & $12 \mathrm{~m}$ & $\begin{array}{l}\text { 5-ASA, } \\
\text { steroids }\end{array}$ \\
\hline
\end{tabular}

*Searle, USA. ASA Aminosalicylic acid; Bx Biopsy; Dx Diagnosis; Endo Endoscopy; F Female; M Male; $m$ Months; Sx Symptoms

inflammation is less clear. GLP-2 has significant anti-inflammatory actions in the intestinal mucosa, acting via a novel neuronally mediated pathway (10-13). It has been shown that the administration of exogenous GLP-2 significantly decreases permeability characteristics in the small intestine in normal animals and in animals adapting following a massive small bowel resection $(8,14)$. This may be significant because very few known drugs or therapies can reduce gut leakiness $(15,16)$. Conversely, a variety of systemic disease states and postinflammatory states have been related to increases in intestinal permeability. Given the theory that Crohn disease may, in part, be caused by an initial abnormality in intestinal permeability, it is possible that this initial permeability defect may be related to abnormalities in GLP-2 release or in the response to the hormone (17-20).

The effects of acute inflammation on GLP-2 release and activity are not well understood. In patients with Crohn disease, GLP-2 levels may be predicted to vary depending on disease activity and the segment of intestine affected. From the results obtained in normal patients, patients with acute Crohn disease with associated malabsorption and diarrhea would be expected to have an increase in mealstimulated GLP-2 levels $(21,22)$ unless the inflammation itself affects L-cell sensitivity. Furthermore, an increase in GLP-2 production may be a feature of the natural healing or anti-inflammatory response of the intestine, which in turn may also influence intestinal permeability $(12,13)$. In previous studies involving adults with both Crohn disease and ulcerative colitis, fasting levels of GLP-2 were found to be elevated compared with controls; however, disease activity was not quantified (23). A study involving patients with mixed inflammatory bowel disease (IBD) with mild disease showed a normal GLP-2 response to a meal (24). In a preliminary study involving children hospitalized with acute Crohn disease (25), we demonstrated reduced postprandial GLP-2 levels; the effect of active ileal Crohn disease on stimulated (postprandial) release of GLP-2 levels is unclear.

In the present study, we investigated meal-stimulated GLP-2 production and, at the same time, intestinal function in pediatric patients with an acute flare of Crohn disease, comparing them with controls and with themselves once the disease was in remission. We hypothesized that acute inflammation would reduce postprandial GLP-2 release, despite ongoing nutrient malabsorption, and that this would normalize once the inflammation subsided.

\section{METHODS}

The present study was designed as both a comparative study, with affected patients compared with normal controls, and a longitudinal study, comparing patients with themselves after resolution of the acute flare of IBD. Patients were evaluated at intake and Crohn disease activity was quantified using a clinical Crohn index tool. At study commencement, there was uncertainty regarding the responsiveness of the pediatric index due to the inclusion of linear growth as an input; therefore, the adult index was used (26,27). GLP-2 levels were quantified at baseline (fasting) and after a mixed meal of $6 \mathrm{kCal} / \mathrm{kg}$ to $8 \mathrm{kCal} / \mathrm{kg}$ (postprandial). Intestinal function was quantified using the urinary recovery of carbohydrate probes. Patients were subsequently treated by their primary physician and, after symptom resolution (six to eight weeks), patients were re-evaluated and comparisons made both with their initial values and with contemporaneous healthy controls.

\section{Subjects}

Ethical considerations: Patients were recruited after evaluation at a tertiary pediatric gastroenterology clinic for IBD symptoms and the decision for admission for acute treatment had been made by the treating team. The study inclusion criteria were: a diagnosis of Crohn disease (primarily confined to the small intestine) confirmed by endoscopy; and a Crohn disease activity index (CDAI) >150 (27). Patients were enrolled at the initial diagnosis or during a flare; typically they were on oral medication (5-aminosalicylic acid or lowerdose steroids) only. On admission, the treating physicians would notify the study team, who would approach the patient and their family regarding enrollment; informed consent and assent were obtained. Controls were recruited by advertisement from local schools.

Patients were excluded if they had a current need for or had previously undergone intestinal surgery (regardless of whether related to IBD or other causes), or had significant obstructive symptoms, evidence of fixed intestinal stricture, renal impairment, current or recent documented small bowel infection, diabetes mellitus or major endocrine abnormalities requiring treatment.

Interventions: After informed consent, all patients completed a baseline standard case report form with a study investigator, including a full gastroenterological functional survey, with questions specifically on the use of acetylsalicylic acid and other anti-inflammatory medications, alcohol and smoking habits. The patients completed a CDAI questionnaire (26). Typically, on the night of admission, intestinal permeability studies were performed using previously described methods (28). Briefly, patients consumed a regular evening meal; however, $3 \mathrm{~h}$ before bedtime they drank a solution containing lactulose $5 \mathrm{~g}$, mannitol $2 \mathrm{~g}$, and 3-O-methyl-glucose (3-OMG) $5 \mathrm{~g}$ in $200 \mathrm{~mL}$ of water (all sugars USP, from Biosource, Canada). All urine for the subsequent $12 \mathrm{~h}$ was collected, with $5 \mathrm{~mL}$ of thymol (5\%) added to the storage container for preservation and stored frozen. Urine samples were subsequently analysed using high-performance liquid chromatography $(28,29)$.

The morning following admission, before starting active therapy, patients underwent an assessment of GLP-2 levels. GLP-2 levels were analyzed from blood samples drawn after fasting and 45 min after beginning a standardized meal of $6 \mathrm{kCal} / \mathrm{kg}$ to $8 \mathrm{kCal} / \mathrm{kg}$ of Carnation Instant Breakfast (Nestle, Canada). Blood samples were drawn by venipuncture, specimens were immediately stored on ice in a $10 \%$ volume of Trasylol EDTA (Miles, Canada) and centrifuged within $30 \mathrm{~min}$. The resulting plasma was stored at $-20^{\circ} \mathrm{C}$ for subsequent batch analysis as previously described. GLP-2 levels were measured using a radioimmunoassay specific for the $\mathrm{N}$-terminus of intact human GLP-2 (amino acid residues 1 to 33; antibody code 92160), with a sensitivity of $1 \mathrm{pmol} / \mathrm{L}$ and an interassay variation of $5 \%$ at a GLP- 2 concentration of $40 \mathrm{pmol} / \mathrm{L}$ (21). Each sample was analyzed in duplicate.

Patients were subsequently treated by the admitting gastroentrology physician, and typically underwent endoscopy with biopsy to confirm the diagnosis, either at the initial hospitalization or as an outpatient. However, the biopsies were performed a variable time after beginning therapy and, therefore, were not well correlated with disease status but did confirm the disease and ileal involvement. Therapy was directed by the attending physician and typically consisted of a short course of high-dose steroids followed by an early introduction of an immunomodulator such as azathioprine and a rapid wean of steroids (30). Patients were followed as outpatients after discharge, and the follow-up sampling was completed from six to eight weeks following 
TABLE 2

Crohn disease patients: Acute flare

\begin{tabular}{|c|c|c|c|c|c|c|c|c|}
\hline \multirow[b]{2}{*}{ Patient } & \multirow[b]{2}{*}{ Age, years } & \multirow[b]{2}{*}{ CDAI } & \multicolumn{2}{|c|}{ GLP-2 levels, pmol/L } & \multicolumn{3}{|c|}{ Sugar absorption, \% } & \multirow[b]{2}{*}{ Ratio } \\
\hline & & & Fasting & Postprandial & 3-OMG & Lactulose & Mannitol & \\
\hline 1 & 13 & 190 & 13 & 19 & 49.9 & 1.4 & 15.2 & 0.092 \\
\hline 2 & 15 & 180 & 11 & 24 & 51.8 & 0.7 & 18.1 & 0.039 \\
\hline 3 & 15 & 210 & 14 & 20 & 40.7 & 2.1 & 23.6 & 0.092 \\
\hline 4 & 11 & 220 & 25 & 25 & 39.2 & 1.3 & 25.1 & 0.039 \\
\hline 5 & 17 & 180 & 14 & 22 & 41.3 & 0.9 & 18.4 & 0.041 \\
\hline 6 & 14 & 190 & 11 & 12 & 37.6 & 0.6 & 17.7 & 0.034 \\
\hline 7 & 18 & 200 & 45 & 47 & 43.5 & 1.4 & 26.2 & 0.056 \\
\hline Mean \pm SD & $15.3 \pm 1.3$ & $196 \pm 15^{\dagger}$ & $19.0 \pm 12.4$ & $24.1 \pm 10.9 * \dagger$ & $43.4 \pm 5.4^{\star \dagger}$ & $1.20 \pm 0.51$ & $20.6 \pm 4.3^{\star \dagger}$ & $0.056 \pm 025^{\star \dagger}$ \\
\hline
\end{tabular}

Glucagon-like peptide 2 (GLP-2) levels determined by radioimmunoassay using a specific antibody for intact GLP-2 (amino acid residues 1 to 33) (20). Sugar probe absorption is reported as the proportion of orally administered probe recovered in urine after an overnight collection, quantified using high-performance liquid chromatography $(23,34) .{ }^{*}<<0.05$ versus controls; ${ }^{\dagger} P<0.01$ versus patients in remission (by ANOVA). 3-OMG 3-O-methyl glucose; CDAl Crohn disease activity index

TABLE 3

Crohn disease patients: Remission

\begin{tabular}{|c|c|c|c|c|c|c|c|c|c|}
\hline \multirow[b]{2}{*}{ Patient } & \multirow{2}{*}{$\begin{array}{l}\text { Interval between } \\
\text { studies, weeks }\end{array}$} & \multirow[b]{2}{*}{ Treatment } & \multirow[b]{2}{*}{ CDAI } & \multicolumn{2}{|c|}{ GLP-2 levels, pmol/L } & \multicolumn{3}{|c|}{ Sugar absorption, \% } & \multirow[b]{2}{*}{ Ratio } \\
\hline & & & & Fasting & Postprandial & 3-OMG & Lactulose & Mannitol & \\
\hline 1 & 8 & Steroids $\rightarrow$ Aza & 80 & 14 & 28 & 74.0 & 1.0 & 42.6 & 0.024 \\
\hline 2 & 8 & Steroids $\rightarrow$ Aza & 110 & 27 & 40 & 76.2 & 1.2 & 45.1 & 0.031 \\
\hline 3 & 12 & Steroids $\rightarrow$ Aza & 60 & 17 & 33 & 63.9 & 1.3 & 29.6 & 0.046 \\
\hline 4 & 10 & Steroids $\rightarrow$ Aza & 120 & 22 & 36 & 57.3 & 1.4 & 27.3 & 0.045 \\
\hline 5 & 12 & Steroids $\rightarrow$ Aza & 80 & 18 & 41 & 62.7 & 0.85 & 28.2 & 0.033 \\
\hline 6 & 10 & Steroids & 80 & 13 & 34 & 46.0 & 0.7 & 31.9 & 0.021 \\
\hline 7 & 8 & Steroids $\rightarrow$ Aza & 120 & 53 & 60 & 44.1 & 1.1 & 43.9 & 0.026 \\
\hline Mean \pm SD & & & $93 \pm 24$ & $23.9 \pm 14$ & $38.9 \pm 10.3$ & $60.6 \pm 12.5$ & $1.08 \pm 0.25$ & $35.5 \pm 8$ & $0.032 \pm 0.010$ \\
\hline
\end{tabular}

Glucagon-like peptide 2 (GLP-2) levels determined by radioimmuno assay using a specific antibody for intact GLP-2 (amino acid residues 1 to 33) (20). Sugar probe absorption is reported as the proportion of orally administered probe recovered in urine after an overnight collection, quantified using high-performance liquid chromatography (23,34). 3-OMG 3-O-methyl glucose; AZA Azathioprine; CDAl Crohn disease activity index

the initial hospital admission, after completion of the initial therapy and the weaning of ongoing steroids. All patients were off steroids at the time of the follow-up assessment. No other exclusions regarding other ongoing treatments were made. Control patients were similarly studied on an outpatient basis.

\section{Statistical methods}

GLP-2 levels, permeability and glucose absorption data and CDAI scores were compared within the same patients using the Student's paired $t$ test. Data from the different disease activity time points and the normal controls was compared using ANOVA, with post hoc testing using the Tukey method with significance set at $\mathrm{P}<0.05$. Comparisons were performed using Prism 4.0 software (Prism Corporation, USA)

\section{RESULTS}

Over the years of the present study (2004 to 2007), 14 patients with appropriate clinical scenarios were approached for enrollment and 12 agreed. Three were started on treatment before the preliminary blood work or absorption studies could be initiated, and two underwent biopsies or endoscopic results that showed primarily a colitis picture and, were threfore, excluded from further analysis. This left seven patients who completed the studies; their baseline characteristics are shown in Table 1. All patients were treated with an acute dose of steroids and the majority were then treated with azathioprine; all were off steroids at the time of the remission studies. GLP-2 levels and sugar absorption results are presented in Tables 2 and 3 , and the results of the control patients are shown in Table 4.

In patients with active Crohn disease, the CDAI showed significant disease as anticipated in a hospitalized population, ranging from 180 to 220 (Table 2). In these patients, the fasting GLP-2 levels were appropriate and not different from controls (Table 3). However, the postprandial levels of GLP-2 were lower in the patients with active Crohn disease and, in fact, showed no significant effect of the meal stimulation (meal-stimulated GLP-2 levels in patients with active disease $24.1 \pm 10.9 \mathrm{pmol} / \mathrm{L}$ versus controls $30.4 \pm 6.6 \mathrm{pmol} / \mathrm{L} ; \mathrm{P}<0.05)$. These normalized with resolution of the disease (patients in remission: $38.9 \pm 10.3 \mathrm{pmol} / \mathrm{L} ; \mathrm{P}<0.001)$. All patients were able to tolerate the meal stimulation of $6 \mathrm{kCal} / \mathrm{kg}$.

In examining nutrient absorption, patients with active disease demonstrated reduced glucose uptake (3-OMG: active disease $43.4 \pm 5.4$ versus patients in remission $60.6 \pm 12.5[\mathrm{P}<0.01]$; and controls 55.7 $\pm 8.7[\mathrm{P}<0.05]$ [\% uptake of orally administered 3-OMG]). Mucosal intestinal permeability as measured by the lactulose/mannitol absorption was increased in patients with active disease (Table 1: active disease $0.056 \pm 0.025$ versus remission $0.032 \pm 0.010[\mathrm{P}<0.05]$; and versus controls $0.029 \pm .008[\mathrm{P}<0.01])$. This was associated with a decrease in mannitol absorption in the patients with active Crohn disease (active disease: $20.6 \pm 4.3$ versus quiescent: $35.5 \pm 8.0[\mathrm{P}<0.01]$ and versus controls $32.8 \pm 6.9[\mathrm{P}<0.01]$ [\% uptake of orally administered mannitol]). The normalization of the lactulose/mannitol ratio in the Crohn patients with quiescent disease was due to both a modest reduction in lactulose absorption and a significant increase in mannitol absorption.

The results of control patients are summarized in Table 4, and show typical profiles of GLP-2 production and permeability. It was difficult to recruit teenage patients; the tested subjects were largely recruited as siblings of participants in other studies (31).

\section{DISCUSSION}

The present study showed that in pediatric patients with active ileal Crohn disease, the expected postprandial production of GLP-2 was blunted despite evidence of reduced nutrient absorption. However, the 


\section{TABLE 4}

\section{Control group}

\begin{tabular}{|c|c|c|c|c|c|c|c|c|c|}
\hline \multirow[b]{2}{*}{ Patient } & \multirow[b]{2}{*}{ Age, years } & \multirow[b]{2}{*}{ Sex } & \multirow[b]{2}{*}{ Tanner stage } & \multicolumn{2}{|c|}{ GLP-2 levels, pmol/L } & \multicolumn{4}{|c|}{ Sugar absorption, \% } \\
\hline & & & & Fasting & Postprandial & 3-OMG & Lactulose & Mannitol & Ratio \\
\hline 1 & 8 & Female & 2 & 17 & 42 & 76.3 & 1.39 & 43.2 & 0.032 \\
\hline 2 & 9 & Female & 2 & 18 & 28 & 56.8 & 0.71 & 40.6 & 0.017 \\
\hline 3 & 6 & Male & 2 & 17 & 33 & 44.1 & 0.96 & 25.68 & 0.037 \\
\hline 4 & 7 & Male & 2 & 16 & 26 & 48.2 & 1.23 & 36.06 & 0.034 \\
\hline 5 & 8 & Female & 2 & 13 & 34 & 90.4 & 0.98 & 37.61 & 0.026 \\
\hline 6 & 10 & Female & 2 & 14 & 23 & 56.6 & 0.85 & 27.58 & 0.030 \\
\hline 7 & 8 & Male & 2 & 18 & 24 & 49.7 & 0.76 & 24.00 & 0.032 \\
\hline 8 & 10 & Male & 3 & 14 & 21 & 53.7 & 0.64 & 36.91 & 0.017 \\
\hline 9 & 7 & Female & 2 & 15 & 26 & 54.7 & 1.07 & 25.52 & 0.041 \\
\hline 10 & 10 & Male & 3 & 20 & 38 & 61.3 & 1.05 & 31.22 & 0.033 \\
\hline Mean \pm SD & $10.3 \pm 1.6$ & & & $16.2 \pm 2.2$ & $30.4 \pm 6.6$ & $55.7 \pm 8.7$ & $0.96 \pm 0.23$ & $32.8 \pm 6.9$ & $0.030 \pm 0.008$ \\
\hline
\end{tabular}

Glucagon-like peptide 2 (GLP-2) levels determined by radioimmunoassay using a specific antibody for intact GLP-2 (amino acid residues 1 to 33) (20). Sugar probe absorption is reported as the proportion of orally administered probe recovered in urine after an overnight collection, quantified using high-performance liquid chromatography (23,34). 3-OMG 3-O-methyl glucose

production of GLP-2 normalized with disease remission. As expected, in acute Crohn disease, there was a reduction in the effective absorptive villae surface area as reflected by the significant reductions in both 3-OMG absorption and mannitol. This was presumably secondary to small intestinal damage. With disease remission, both of these parameters improved, with a reduction in lactulose permeation and, consequently, relative small intestinal permeability declined.

Examining the primary end point of the study, the relationship between GLP-2 production and release to ileal inflammation, the results suggest that ileal inflammation reduces meal-stimulated release of GLP-2. In model systems, GLP-2 release by L-cells is controlled both by intrinsic neuronal stimulation as well as direct input from nutrients within the intestinal lumen $(5,6)$. In human patients, nutrient contact in the terminal ileum and colon appears to be an important factor, while the effect of neuronal input is difficult to discern $(7,32)$. The overall number of L-cells appears to be remarkably stable, and different reports have suggested that the number of these enteroendocrine cells is either stable or even increased in states of IBD inflammation (33-35). We found that the fasting levels of GLP-2 in patients with active disease were unchanged from normal, which implies a normal number of L-cells, and relatively normal stimulatory milieu of neuronal input and luminal nutrient content $(5,6)$. However, with disease resolution, a nonspecific elevation in fasting GLP-2 levels in the Crohn patients in remission was apparent, which is congruent with the report by Xiao et al (23), who showed a similar degree of elevation of fasting GLP-2 levels in a mixed population of patients with IBD (both Crohn and ulcerative colitis) assayed using a less specific GLP-2 antibody methodology. More relevant was the study by Schmidt et al (24), which examined GLP-2 levels in a mixed population of patients with IBD, measuring the GLP-2 response to a meal following colonoscopy. In patients with acute Crohn disease or ulcerative colitis inflammation, there was no change in the overall GLP-2 profile, as determined by the area under the curve methodology; however, there was a decrease in the peak GLP-2 level at $45 \mathrm{~min}$ to $60 \mathrm{~min}$ postmeal ingestion (24). These authors also examined the tissue content of GLP-2 and peptide YY, and found no decrease in tissue GLP-2 despite co-existing inflammation. These findings, together with the results of the present study, suggest that ileal inflammation may have an effect on GLP-2 release, rather than intracellular production by L-cells. This notion is further supported by the demonstration that patients in the present study exhibited nutrient malabsorption (as suggested by the reduced uptake of $3-\mathrm{OMG}$ ). If this increased load of nutrients reached the ileum, it would be expected to actually drive an increase in GLP-2 production in patients with active disease.

A limitation of the present study was that more detailed assessments of the GLP-2 production profile or detailed balance studies to quantify nutrient absorption more fully (especially fat, which is likely the most relevant stimulus of GLP-2 production) could not be obtained due to ethical constraints. Further studies are suggested to better establish the direct effects of acute and chronic inflammation on GLP-2 release and the indirect effects caused by inflammationinduced alterations in nutrient absorption.

It is also possible that the medications that the patients were treated with may have had an impact on GLP-2 release; however, only three were on oral steroids before admission and three were receiving 5-aminosalicylic acid, while post-therapy all patients had been treated with high-dose steroids and then tapered, and were also receiving azathioprine. Despite these more aggressive medication regimens, GLP-2 release was improved. These potential interactions, including the effects of more novel biological therapies, will require more detailed exploration with future studies $(5,6)$. An additional limitation was that the control patients were not closer in age and maturity to the study group; it was not possible to recruit teenagers into the protocol who were not relatives of the patients, which would have potentially confounded the results $(19,36)$. It has been demonstrated that beyond infancy, the postprandial release of GLP-2 is stable; similarly, the permeability characteristics of the intestine are also constant through this age range $(21,37,38)$ and, therefore, the results from the control group are likely comparable with the study subjects if they were healthy.

These results are also interesting from the perspective of the relationship between intestinal permeability and the underlying pathogenesis of IBD. The present results confirm an increase in intestinal permeability in pediatric patients with active Crohn disease. A few points are worth noting in this regard. First, the lactulose/mannitol ratio in our controls was slightly higher than normally reported, even by our group (18). This may be due to the inclusion of a direct stimulant of SGLT-1 (3-OMG) in the test because activation of this transport system is known to open the paracellular junctions. Second, it was likely that with active Crohn disease there was a marked reduction in small intestinal villus tip surface area. This was evident in terms of both paracellular passive absorption (mannitol uptake) as well as active transcellular absorption (3-OMG). This reduction in effective small intestinal surface area was reversible with disease resolution, suggesting that it was related to active inflammation. These data do support the notion that in humans, as in animal models, that it is GLP-2 postprandial secretion or the peak levels that regulate active small intestinal surface area $(4,39,40)$. Thus, inflammation-induced reduction in GLP-2 production may further compound the reduction in nutrient absorptive capacity that the inflammation itself may cause.

In our patients with quiescent Crohn disease, there was no change in GLP-2 release following a meal compared with controls within the 
limits of our methodology. This, coupled with the lack of change in permeability in this same group, suggests that the hypothesis relating the causality of Crohn disease to a fundamental lack of GLP-2 production and an associated increase in intestinal permeability that precedes or causes eventual disease is unlikely $(19,20,36)$.

The findings of the present study suggest that patients with active ileal Crohn disease experience a reduced meal-stimulated release of GLP-2; this may impact nutrient absorptive capacity as well as trophic mucosal support. Enteral feeding is an effective therapy for pediatric Crohn disease but the specific mechanisms underlying the benefits of this treatment are not clear $(41,42)$. GLP-2 and its analogues have significant anti-inflammatory effects in both animal models of IBD and in limited studies in humans $(12,13,43)$. Meal-stimulated GLP-2 release may be a part of the therapeutic effects of enteral feeding; this relationship deserves further study. A further implication of this relationship would be that patients who have acute inflammation may benefit from nutrient regimens that optimize the release of native GLP-2 (ie, diets containing a high proportion of long-chain fats); this will require specific study (5).

Overall, the results of the present study suggest that acute ileal Crohn disease has an impact on GLP-2 release, which recovers with disease resolution. The findings regarding the relationship between active nutrient absorption and passive permeation by inert sugars confirm the degree of nutrient malabsorption apparent in this patient population but does not support an underlying permeability defect in

\section{REFERENCES}

1. Drucker DJ, Erlich P, Asa SL, Brubaker PL. Induction of intestinal epithelial proliferation by glucagon-like peptide 2. Proc Natl Acad Sci U S A 1996;93:7911-6.

2. Sangild PT, Tappenden KA, Malo C, et al. Glucagon-like peptide 2 stimulates intestinal nutrient absorption in parenterally fed newborn pigs. J Pediatr Gastroenterol Nutr 2006;43:160-7.

3. Cottrell JJ, Stoll B, Buddington RK, et al. Glucagon-like peptide-2 protects against TPN-induced intestinal hexose malabsorption in enterally refed piglets. Am J Physiol Gastrointest Liver Physiol 2006;290:G293-G300.

4. Martin GR, Wallace LE, Sigalet DL. Glucagon-like peptide-2 induces intestinal adaptation in parenterally fed rats with short bowel syndrome. Am J Physiol Gastrointest Liver Physiol 2004;286:G964-G972.

5. Brubaker PL, Anini Y. Direct and indirect mechanisms regulating secretion of glucagon-like peptide-1 and glucagon-like peptide-2. Can J Physiol Pharmacol 2003;81:1005-12.

6. Roberge JN, Brubaker PL. Secretion of proglucagon-derived peptides in response to intestinal luminal nutrients. Endocrinology 1991;128:3169-74.

7. Jeppesen PB, Hartmann B, Hansen BS, Thulesen J, Holst JJ, Mortensen PB. Impaired meal stimulated glucagon-like peptide 2 response in ileal resected short bowel patients with intestinal failure. Gut 1999;45:559-63.

8. Martin GR, Wallace LE, Hartmann B, et al. Nutrient stimulated GLP-2 release and crypt cell proliferation in experimental short bowel syndrome. Am J Physiol Gastrointest Liver Physiol 2004;288:G431-G438.

9. Meier JJ, Nauck MA, Pott A, et al. Glucagon-like peptide 2 stimulates glucagon secretion, enhances lipid absorption, and inhibits gastric acid secretion in humans. Gastroenterology 2006;130:44-54.

10. Boushey RP, Yusta B, Drucker DJ. Glucagon-like peptide 2 decreases mortality and reduces the severity of indomethacin-induced murine enteritis. Am J Physiol 1999;277:E937-E947.

11. Jeppesen PB, Sanguinetti EL, Buchman A, et al. Teduglutide (ALX-0600), a dipeptidyl peptidase IV resistant glucagon-like peptide 2 analogue, improves intestinal function in short bowel syndrome patients. Gut 2005;54:1224-31.

12. Ivory CP, Wallace LE, McCafferty DM, Sigalet DL. Interleukin-10. independent anti-inflammatory actions of glucagon-like peptide 2 . Am J Physiol Gastrointest Liver Physiol 2008;295:G1202-G1210.

13. Sigalet DL, Wallace LE, Holst JJ, et al. Enteric neural pathways mediate the anti-inflammatory actions of glucagon-like peptide 2 . Am J Physiol Gastrointest Liver Physiol 2007;293:G211-G221. these patients. The continued exploration of the relationship between nutrients and the response of the intestinal mucosa in IBD patients is encouraged, so that both the nutritional support of this vulnerable population and the opportunities to harness the beneficial antiinflammatory actions of enteral nutrition are optimized.

ACKNOWLEDGEMENTS: Funding was provided by operating grants from the Crohn and Colitis Foundation of Canada (CCFC, to DLS). Dr Kravarusic was supported by a Kinsman Research Fellowship of the Alberta Children's Hospital Research Foundation. Infrastructure support for the Sigalet laboratory comes from the Professorship in Pediatric Surgical Research, funded by the Alberta Children's Hospital Research Foundation.

CONTRIBUTIONS: DL Sigalet led the study conception and design, interpretation of data, and drafting of manuscript, DK led data acquisition, and initial analysis, $\mathrm{BH}$ and $\mathrm{JH}$ contributed to sample analysis, all authors contributed to analysis of the data, critical review and editing of the manuscript. The technical assistance of Laurie Wallace and Kim Tran is gratefully acknowledged.

DISCLOSURES: DL Sigalet has acted as a paid consultant regarding the development of a glucagon-like peptide 2 ligand for Nycomed Corporation. The remaining authors declare that they have no competing interests.

14. Martin GR, Meddings JB, Sigalet DL. 3-0 methylglucose absorption in vivo correlates with nutrient absorption and intestinal surface area in experimental short bowel syndrome. J Parenter Enteral Nutr 2003;27:65-70.

15. Bijlsma MF, Peeters RA, Groot JA. Differential in vivo and in vitro intestinal permeability to lactulose and mannitol in animals and humans: A hypothesis. Gastroenterology 1995;108:687-96.

16. Bjarmason I, Macpherson A, Hollander D. Intestinal permeability: An overview. Gastroenterology 1996;108:1581.

17. Abraham C, Cho JH. Inflammatory bowel disease. N Engl J Med 2009;361:2066-78

18. Meddings J. Barrier dysfunction and Crohn's disease. Ann N Y Acad Sci 2002;915:333-8.

19. Irvine EJ, Marshall JK. Increased intestinal permeability precedes the onset of Crohn's disease in a subject with familial risk. Gastroenterology 2000;119:1740-4.

20. Salim SY, Soderholm JD. Importance of disrupted intestinal barrier in inflammatory bowel diseases. Inflamm Bowel Dis 2011;17:362-81.

21. Hartmann B, Johnsen AH, Orskov C, Adelhorst K, Thim L, Holst JJ. Structure, measurement, and secretion of human glucagon-like peptide-2. Peptides 2000;21:73-80.

22. Xiao Q, Boushey RP, Drucker DJ, Brubaker PL. Secretion of the intestinotropic hormone glucagon-like peptide 2 is differentially regulated by nutrients in humans. Gastroenterology 1999;117:99-105.

23. Xiao Q, Boushey RP, Cino M, Drucker DJ, Brubaker PL. Circulating levels of glucagon-like peptide-2 in human subjects with inflammatory bowel disease. Am J Physiol Regulatory Integrative Comp Physiol 2000;278:R1057-R1063.

24. Schmidt PT, Ljung T, Hartmann B, Hare KJ, Holst JJ, Hellstrom PM. Tissue levels and post-prandial secretion of the intestinal growth factor, glucagon-like peptide-2, in controls and inflammatory bowel disease: Comparison with peptide YY. Eur J Gastroenterol Hepatol 2005;17:207-12.

25. Kravarusic D, Holst J, Wallace LE, Sigalet DL. Effects of inflammation in Crohn's disease on meal stimulated GLP-2 levels. J Pediatr Surg 2006;37(Symposium Proceedings):A134. (Abst)

26. Sandler RS, Jordan MC, Cooper LL. Development of a Crohn's index for survey research. Clin Epidemiol 1988;41:451-8.

27. Otley A, Loonen H, Parekh N, Corey M, Sherman PM, Griffiths AM. Assessing activity of pediatric Crohn's disease: Which index to use? Gastroenterology 1999;116:527-31.

28. Sigalet DL, Martin G, Meddings J, Hartman B, Holst JJ. GLP-2 levels in infants with intestinal dysfunction. Pediatr Res 2004;56:371-6. 
29. Sigalet DL, Martin GR, Meddings JB. 3-0 methylglucose uptake as a marker of nutrient absorption and bowel length in pediatric patients. J Parenteral Enteral Nutr 2004;28:158-62.

30. Punati J, Markowitz J, Lerer T, et al. Effect of early immunomodulator use in moderate to severe pediatric Crohn disease. Inflamm Bowel Dis 2008;14:949-54.

31. Robertson MA, Sigalet DL, Holst JJ, Meddings JB, Wood J, Sharkey KA. Intestinal permeability and glucagon-like peptide-2 in children with autism: A controlled pilot study. J Autism Dev Disord 2008;38:1066-71.

32. Jeppesen PB, Hartmann B, Thulesen J, et al. Elevated plasma glucagon-like peptide 1 and 2 concentrations in ileum resected short bowel patients with a preserved colon. Gut 2000;47:370-6.

33. El-Salhy M, Danielsson A, Stenling R, Grimelius L. Colonic endocrine cells in inflammatory bowel disease. J Intern Med 1997;242:413-9.

34. Lomax AE, Linden DR, Mawe GM, Sharkey KA. Effects of gastrointestinal inflammation on enteroendocrine cells and enteric neural reflex circuits. Auton Neurosci 2006;126-127:250-7.

35. O'Hara JR, Ho W, Linden DR, Mawe GM, Sharkey KA.

Enteroendocrine cells and 5-HT availability are altered in mucosa of guinea pigs with TNBS ileitis. Am J Physiol Gastrointest Liver Physiol 2004;287:G998-1007.

36. Hedin CR, Stagg AJ, Whelan K, Lindsay JO. Family studies in Crohn's disease: New horizons in understanding disease pathogenesis, risk and prevention. Gut 2012;61:311-8.
37. Amin H, Holst JJ, Hartmann B, Wallace L, Wright J, Sigalet DL. Functional ontogeny of the proglucagon-derived peptide axis in the premature human neonate. Pediatrics 2008;121:e180-e186.

38. McOmber ME, Ou CN, Shulman RJ. Effects of timing, sex, and age on site-specific gastrointestinal permeability testing in children and adults. J Pediatr Gastroenterol Nutr 2010;50:269-75.

39. Martin GR, Beck PL, Sigalet DL. Gut hormones, and short bowel syndrome: The enigmatic role of glucagon-like peptide- 2 in the regulation of intestinal adaptation. World J Gastroenterol 2006;12:4117-29.

40. Kaji T, Tanaka H, Holst JJ, et al. The effects of variations in dose and method of administration on glucagon like peptide-2 activity in the rat. Eur J Pharmacol 2008;596:138-45.

41. Critch J, Day AS, Otley A, King-Moore C, Teitelbaum JE, Shashidhar $\mathrm{H}$. Use of enteral nutrition for the control of intestinal inflammation in pediatric Crohn disease. J Pediatr Gastroenterol Nutr 2012;54:298-305.

42. Zachos M, Tondeur M, Griffiths AM. Enteral nutritional therapy for induction of remission in Crohn's disease. Cochrane Database Syst Rev 2007;(1):CD000542.

43. Buchman AL, Katz S, Fang JC, Bernstein CN, bou-Assi SG. Teduglutide, a novel mucosally active analog of glucagon-like peptide-2 (GLP-2) for the treatment of moderate to severe Crohn's disease. Inflamm Bowel Dis 2010;16:962-73. 


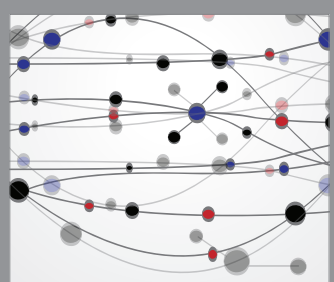

The Scientific World Journal
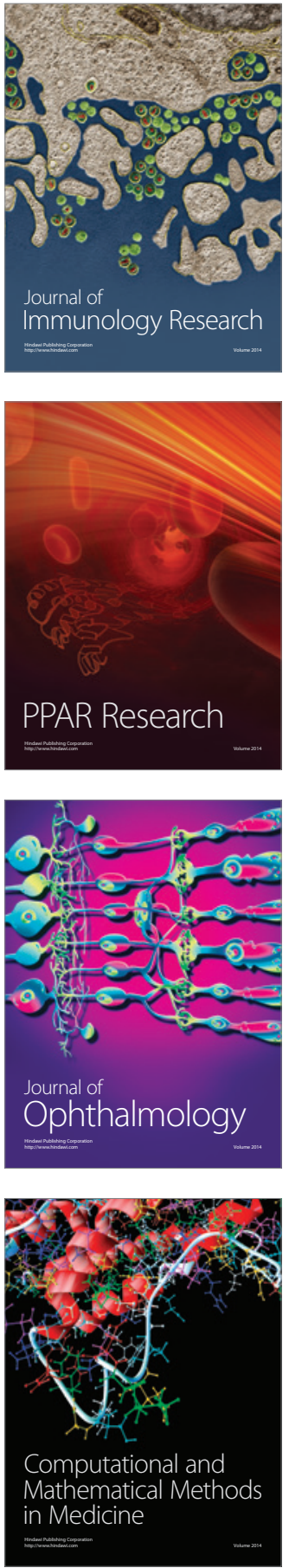

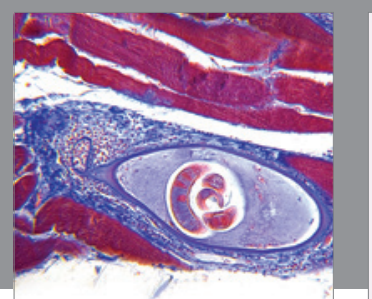

Gastroenterology Research and Practice

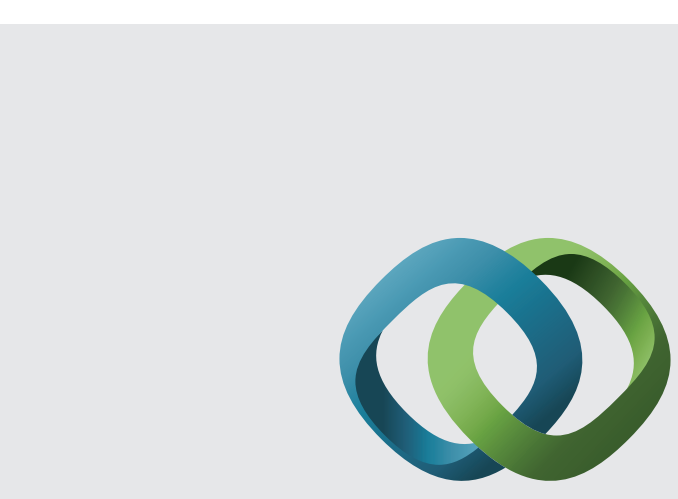

\section{Hindawi}

Submit your manuscripts at

http://www.hindawi.com
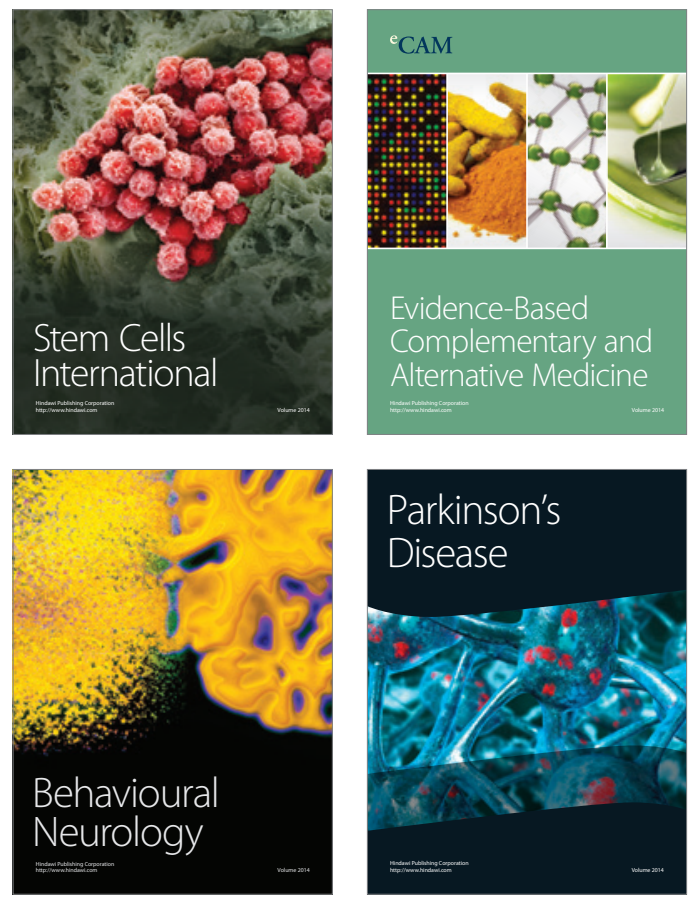
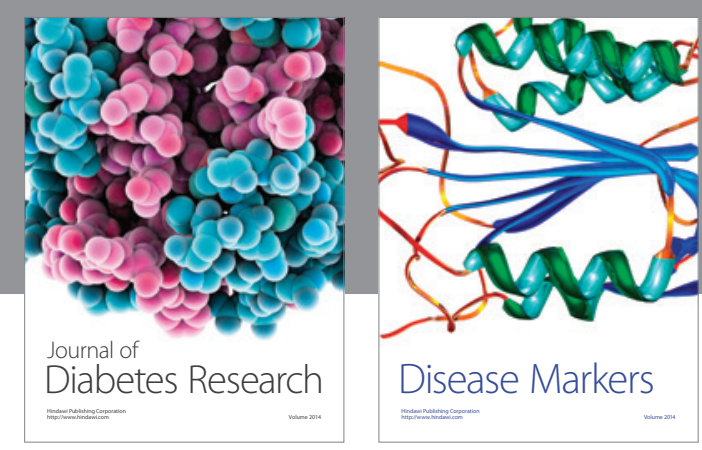

Disease Markers
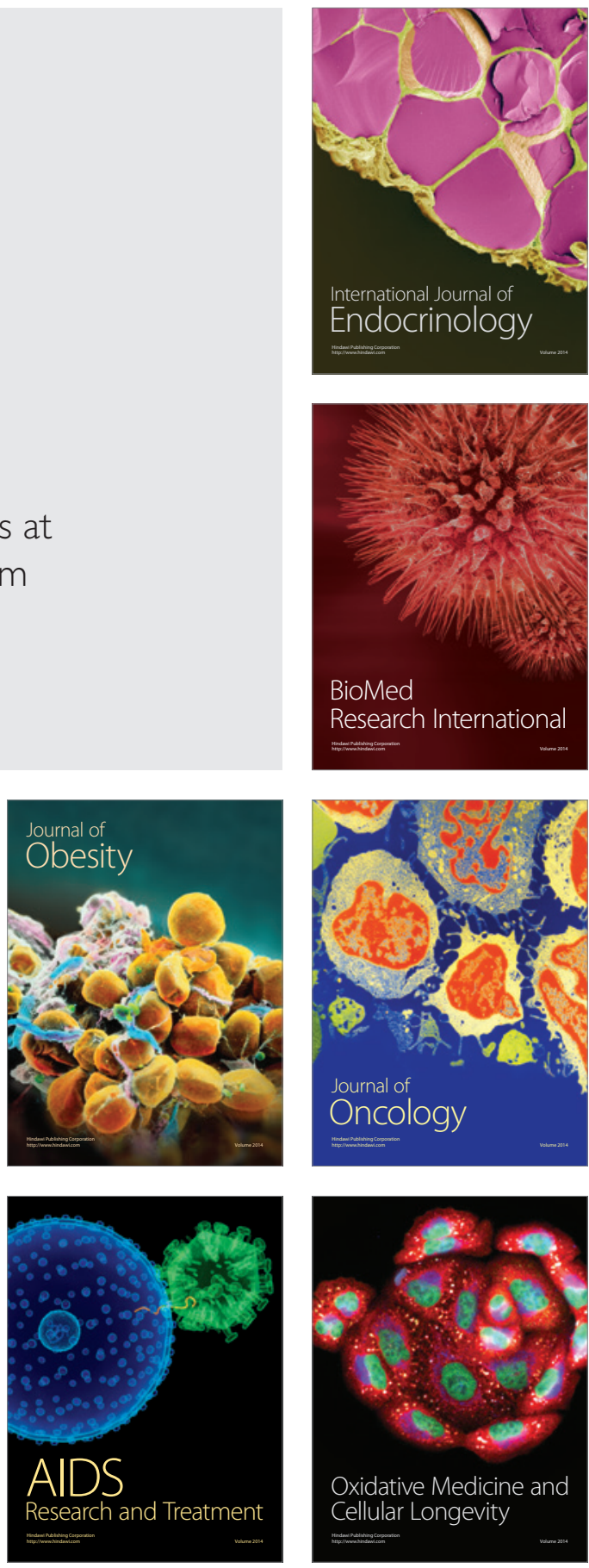